Sergio Blanco Fajardo

\title{
Broadcasting the 'Spanish Woman'. Nationalism and Female Radio Programmes During the Franco Regime
}

\begin{abstract}
This paper aims to show how radio can be envisioned as a witness and agent of the transformations that operated during the forty-year Franco dictatorship in Spain. It analyses a number of radio scripts from the private station Radio Madrid to examine how the radio worked as a means to both affect and be affected by the sociopolitical events of the country. Its focus is on the discourse of programmes aimed at female audiences that exploited and re-educated housewives over the airwaves according to the regime's interests. These programmes therefore served as a catalyst for state policies and the construction of the nationalist Project and also show the contradictions in the new femininity models manifested during the second Franco regime.
\end{abstract}

KeYwords: Radio, Franco's dictatorship, female broadcasts, nationalism, gender history

\section{Introduction}

Spanish broadcasting first started in I924, along with Miguel Primo de Rivera's dictatorship which created the first broadcasting regulations. These encouraged free competition and prevented monopolies, advocating a system of mixed public and private ownership. During the next seven years Spanish radio took shape with the creation of the first broadcasting stations that used modern technologies from England and France. Radio was turned into a political medium when the Republic was proclaimed in I93I and by the outbreak of the civil war in ${ }_{1936}$, fifty radio stations had been set up all over the country. ${ }^{\mathrm{I}}$

The Spanish Civil War (I936-1939) disrupted the role of the radio when both sides noticed the strategic importance of communications and the propagandistic power afforded by the media. The use of this 'weapon of war' was not only military, but also became an essential instrument of propaganda setting up the so-called 'civil front' to keep up the morale of the soldiers. Meanwhile the government ordered, through the radio waves, the withdrawal of the militiawomen from the front so that they could focus on what was considered their more appropriate, traditional maternal role at home. 
Once the Republic was defeated, Franco's government repurposed and gave new meaning to the role of the radio according to circumstantial necessities and interests. After the War, the New State legitimated its position through a long, repressive process. ${ }^{2}$ General Franco's vision of fascism differed from that in Germany and Italy by promoting a country in which there were two groups: the 'defeated', i.e. those who had left-wing ideas, and the 'victorious'. The 'defeated' were socially, culturally, economically and politically discriminated so that civilians, in order to survive, in public pretended to show their sympathy for the regime whilst in private they harboured antipathy towards the dictatorship.

The government broadcasts took on a propagandistic and ideological role to indoctrinate the population according to National Catholicism's doctrine. ${ }^{3}$ From a gender perspective, both men and women participated in a distinct way in the recovery of the country. Housewives committed to cooperating with government policies even in the home. The radio, as a household appliance, became an inseparable friend in their daily life that enlivened the long, domestic workdays. However, the main mission, hidden by feminine broadcasts behind this entertainment screen, was to cement the ideological and political background that the 'Spanish woman' had to possess: meeting her responsibility of being a good mother and wife, a role that involved a series of procedures closely related to dictatorial policy.

This paper contributes to earlier scholarship on gender roles and stereotypes prevalent in and fostered by radio broadcasting, Kate Lacey has explained how broadcasting in Germany in the I930s not only shaped, but also led and transformed both gender roles and stereotypes, while Caroline Mitchell has reflected on the relationship between the audience and radio technology and the capacity of the latter to construct gender differences. ${ }^{4}$ Alexander Badenoch, meanwhile, has analysed the influence of feminine radio programmes on the domestic sphere and how they thereby controlled both the time and space of housewives. 5 The Spanish feminine radio programmes shared some similarities with these studies, i.e. the idea of controlling women, which formed an essential part of rebuilding a post-war nation that promoted once again the placement of housewives in the domestic sphere. Music, recipes, fashion, beauty and childcare all constructed a traditional model for women to help their homelands. The differences lie in the duration in which the Spanish programmes continued to defend Spain's feminine model. From the I950s, democratic European countries, radio programmes started to include a greater range of opinions including ideas that spoke of different, more equal, roles for women. ${ }^{6}$ In Spain though, throughout the Franco dictatorship until I975, despite the economic progress made during that period, radio continued to transmit views of the same self-denying and submissive type of woman.

This article aims to show that the radio was a tool that contributed to the construction of normative gender models during the Franco regime. It also intends to show the readjustment of radio speech to the different political and socioeconomic changes that took place during the Dictatorship, and, finally, to examine the exploitation of housewives who were re-educated over the airwaves according to the regime's interests. In order to do so, this article examines a number of speeches in the scripts of the private radio station Radio Madrid. We will examine two programmes: the first is a programme called Charlas de puericultura (Childcare talks) which will be 
used to explain the political and nationalist implications of women's roles. Then, in order to collect experiences of the second stage of the Franco regime when the country adopted an economic development model based on the introduction of foreign capital and multinational corporations, the creation of industrial centres, the consolidation of the service sector, and law reforms that made the inclusion of single women in the labour market easier, we have chosen the programme Vosotras (You women). This reflects the destabilisation caused by the emergence of other models of femininity and the regime's efforts to control the activity of housewives.

\section{The rebuilding of a nation}

George Orwell wrote in Looking Back on the Spanish War (I943): 'I saw, in fact, history being written not in terms of what happened but of what ought to have happened according to various party lines.'7 He also mentioned the manipulation of radio and the press during the Spanish Civil War and its power to misrepresent reality. During the Franco regime, especially in the first stage (I939-I959), radio built a political discourse similar to the regime's interests. Broadcasts were linked to power structures that supported the Franco regime: the Falangist one-party state, the Church, and the oligarchic core. Legislation empowered these institutions and economic power groups to own broadcasts and radio stations. ${ }^{8}$ The lack of capital after the civil war as well as the stations' technological backwardness created the need for a mixed public-private model. However, in both cases, recordings were made for specific functions. Public radio was born with the aim of informing by assuming a monopoly on information, while private radio maintained

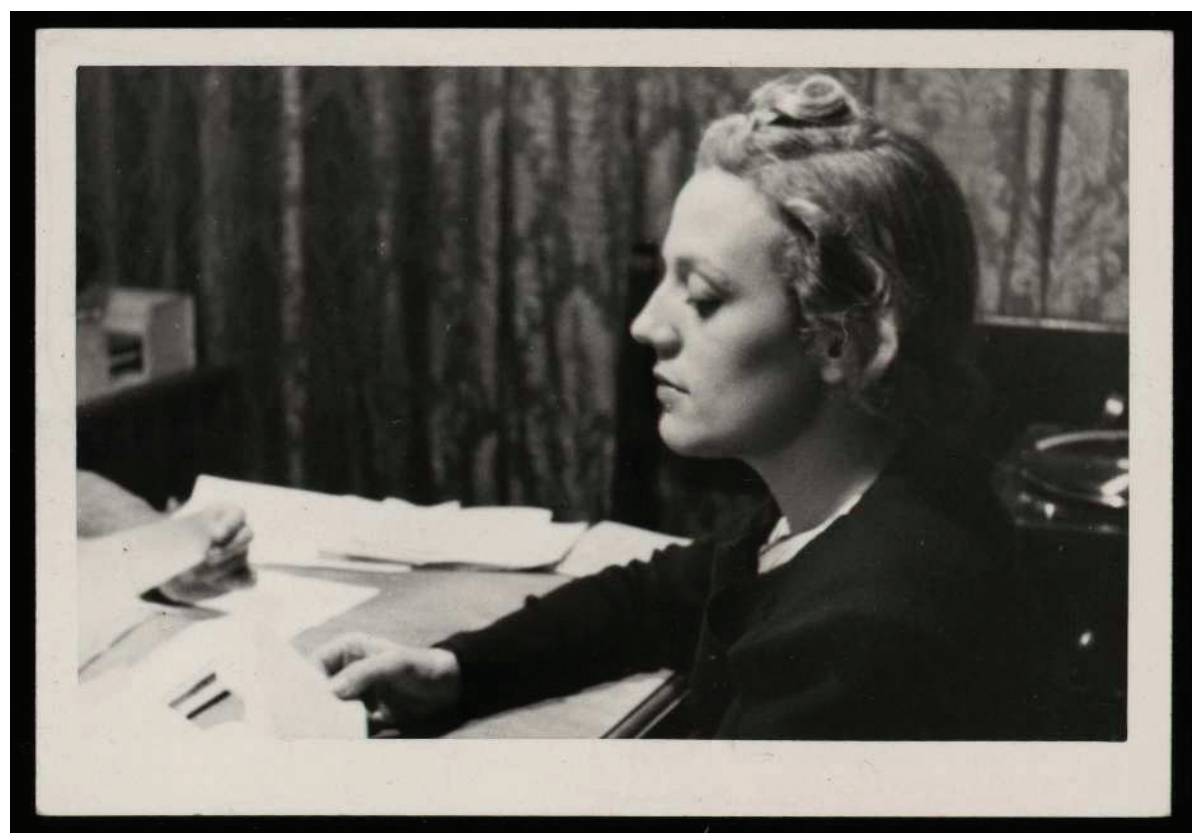

Figure 1. María Luisa Moreno Elorza, broadcaster for Radio Nacional de España, 1938. Spanish National Library, Digitalised Photography Documentary Collection, http://bdh-rd.bne.es/viewer.vm?id=bdhoo00071174. 
the goal of entertaining, at least in theory. In any case, radio programmes were subject to heavy censorship as approved by Ministerial Order of 6 October 1939. According to this regulation, all programming of commercial broadcasters was subject to approval by provincial or local propaganda headquarters, which were organisations in charge of evaluating scripts and censoring anything that contradicted the ideological model of the regime. 9 In addition, a 'purification' process of employees of radio stations took place, i.e. individuals suspected of having supported the Republic, or those who worked during that period, were fired.

The beginning of the Franco dictatorship initiated a nationalist project the discourse of which was focused on the victimisation of the 'real Spain', hurt by the attack of communism. This 'illness', attributed to the harmful nature of the Republican period, had dismantled the spirit of the Spanish nation and caused the impoverishment of the 'Hispanic race', it was argued. The regime's rhetoric tried to legitimise the civil war as a 'crusade' and present Franco as a liberator. Within this narrative, as pointed out by Inmaculada Blasco, 'gender was a key element in the task of recovering the alleged loss of national identity.' ${ }^{\text {Io }}$ The construction of a normative femininity, and espousing of clear responsibilities for men and women, created a bond between political interests and Franco's nationalism. Under what was considered a 'new model' the regime's ideologists recovered and resignified traditional characteristics such as Catholic morality, religiousness and maternity and imposed upon women a militant space, the domestic sphere, to help the nation recover. From this relationship between women and the nation, we can better understand the implication of the nationalist project in the construction of gender models and, furthermore, patriotic contributions made by housewives, subject to their embodiment of feminine nature as mothers and wives.

This process of including women in nationalism and the regime's policies was carried out by the Falange's Sección Femenina (SF) and the Women's Acción Católica (AC). The trajectory of both institutions was bound to an energetic activism aimed at confronting liberal and suffragist feminism that started to be defined in Spain in I9I9. During the Republic, this struggle and the defence of traditional and religious values were based on patriotism and ultra-Catholic concepts. ${ }^{\text {II }}$ Along similar lines - although it should be put into context the militancy of the women of the SF during the last years of the Republic was influenced by the tenets of European fascism, from which they took the slogans of feminine abnegation, submission, and sacrifice to contribute to the anti-republican cause. ${ }^{\mathrm{I2}}$ Giuliana di Febo expresses clearly the circular relation among home, religion, and mother country to define this national task. ${ }^{13}$

The ideological role played by the radio during the dictatorship could be felt in the discourses of feminine programmes. The radio sector introduced policies at the household level, directed towards housewives, by controlling their activity. For example, programmes that broadcast simple recipes or invented pseudo-ingredients to substitute the original ones because they were out of reach in a time of hunger and misery prepared housewives for serving the nation with devotion and frugality. In this sense, the radio catalysed the official discourse and substantially integrated it into these kinds of broadcasts to shape women into the normative feminine archetype. 
Speeches broadcast by Pilar Primo de Rivera contributed to guiding the main actions of the SF members as militants. The following speech may be noted among them:

I know that we will avoid the death of children by preparing mothers; but this is a slow task and Spain is in a hurry to double the number of its inhabitants. For our part, I ensure you that, in order to avoid it, we will not scrimp on media; we will look for everything that science has studied. ${ }^{\mathrm{I}}$

From the beginning, maternity was the main feminine mission and the noblest act of women towards their patriotic duties. The efforts toward a pro-natalist policy supported by the dictator, who wished to reach a population of forty million, involved women as its leading advocates. This aspiration was refined and forged by direct association with the growth of the nation through the race's regeneration and the suitable education of children.

From early on, the radio assimilated the valuable patriotic task that should be carried out by women; thus, childcare radio programmes were not merely entertainment. These broadcasts were imbued with a seriousness stemming from the intrinsic links with the nationalist project and the space in the programme schedule occupied by childcare speeches was adapted to fit housewives' available free time.

The programme Charlas de Puericultura (Childcare Speeches) started in July I94I in the Radio Madrid station, a radio station belonging to the network 'Sociedad Española de Radiodifusión' (SER). ${ }^{15}$ Luisa Trigo Seco, Doctor of Childcare, was in charge of this network. She was not only its voice, but also the author of all the scripts. The programme was broadcast weekly during the after-lunch hours (i6:30), a time period when housewives could pay attention to the radio. ${ }^{16}$ The broadcast continued sporadically for decades, offering help to thousands of women to become real mothers to the homeland. From the first broadcasts, it was obvious that this was different from the rest of the feminine programmes, at the same time as it showed its close relationship to the nationalist project:

Maternity is a commendable function for the nation. The title of mother is an honorary title among those who work for their Homeland. Woman has a relevant post in the society and the family. By taking care of pregnancy hygiene based on this great broadcast, we think that this advice should incite many mothers to come under obstetrician surveillance as a way of getting a healthy, fecund, new life for our Spain. ${ }^{17}$

When comparing Charlas de Puericultura to other programmes, it is notable that the former had a much clearer and more concise message with a very noticeable political connection, i.e. the relationship between maternity and nation represented an indelible link to the State.

The pro-natalist policy attempted to hide the lagging population of the nation by blaming the ignorance and lack of education of mothers as the cause of post-neonatal mortality. ${ }^{18}$ The way to redeem this 'sin' involved the 'scientific' education of mothers, an activity that Charlas de 
puericultura knew how to emphasise: 'The woman, militant of the practical childcare, by acting in a strong way with the children, does a beautiful labour for the Race that is, at the same time, a patriotic work.' 19 It is interesting to note the link between the mother and militancy for the national cause. This connection suggests an unequivocal mechanism of politicisation of maternity that, by extension, appoints women as political agents of the regime and redirected their maternity as a nationalist act:

The child, radio listener ladies, is 'His Majesty the Kid' for the Spain of el Caudillo'o, is an axis, and is a centre. He is a racial necessity for the Victorious Spain, is its cultivation, and every imperial project is firmly based on a brave and strong youth that possesses a spirit of endeavour and adventure because it is big, vigorous, expandable and heroic. ${ }^{21}$

Even though the militant role was situated in the domestic sphere, the radio message pressed to rebuild the homeland or the nation, both concepts that redirect their meanings towards a public aspect. As mentioned by Badenoch, the interconnectedness and boundaries between the public and private spheres invites us to think about the ability of the radio to articulate aspects of both. ${ }^{22}$ As other models of femininity appeared, radio was witness to the permeability of the domestic and the public spheres and operated through the plans of the regime during a period full of changes and tensions.

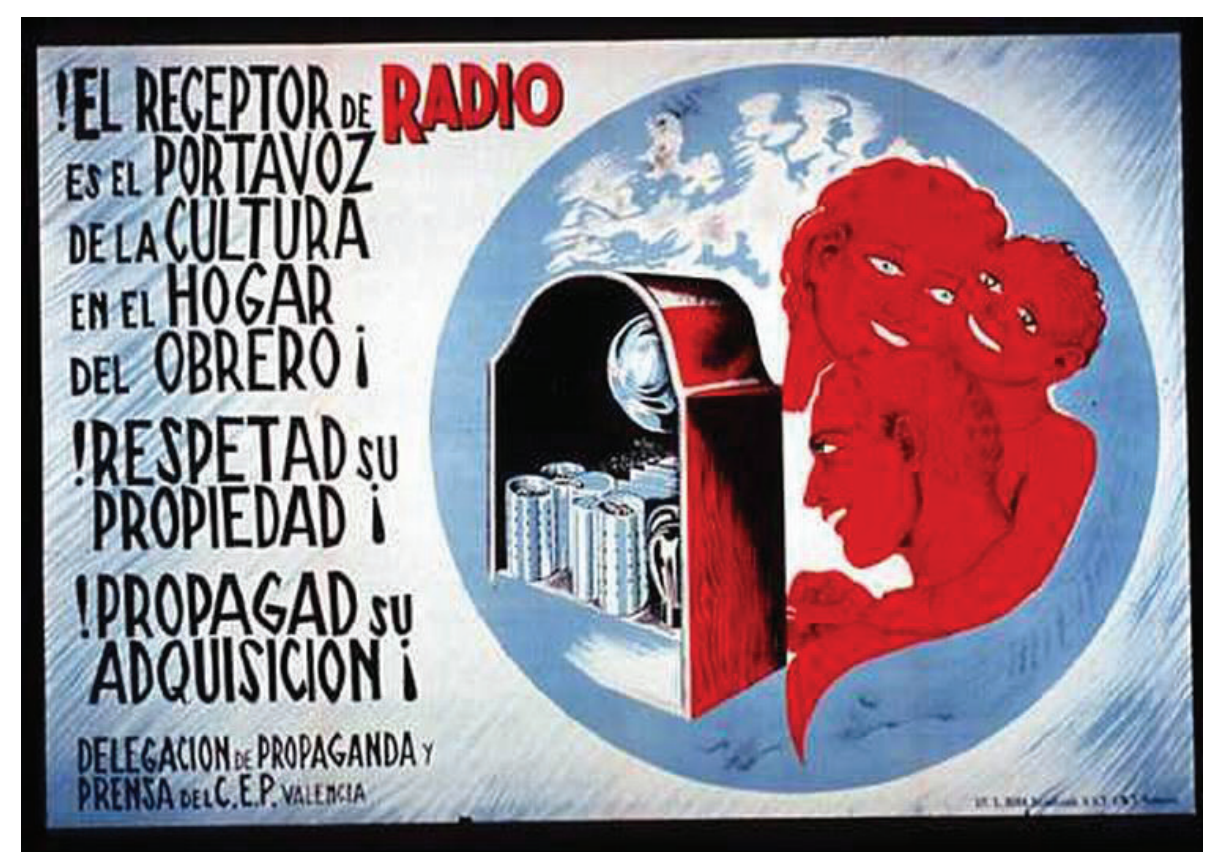

Figure 2. Poster for the Propaganda and Press Delegation of the Popular Executive Committee of Valencia, 1936-1937. Source: Pablo Iglesias Foundation Archive. 


\section{The new Spanish paradigm: the radio and the socioeconomic development. Towards a new archetype of the 'modern woman'}

The Stabilisation Plan of 1959 developed an economic reform policy focused on abandoning the autarchy and establishing an industrial and financial capitalist model. From I953, the first moves toward this plan were felt after an agreement with the United States. This date marked the process known as 'pre-developmental' that tried to lay the foundations for transition towards the new economic paradigm. During this stage of changes, the social and cultural fields were shaken in the same way. The ideal of femininity, the 'queen of the home' or the 'perfect wife', slowly underwent transformations in the late '50s. ${ }^{23}$ During this decade of transition, the changes that made the emergence of another ideal of gender - the 'modern woman' - possible during the "6os were in the works. The entry into the labour market and the consumer role added to the traditional role of wife and mother were the defining features of this ideal and those that made the difference. ${ }^{24}$

Broadcasting also favoured changes, such as the emergence of the star system, the distribution of the first transistor radios and the increase of broadcasts that consolidated the advertising business. ${ }^{25}$ The radio explored sociocultural tensions between the new consumer woman model and the traditional archetype. The need to increase purchasing power and introduce mass consumption gave rise to the surge of single women as well as housewives, when allowed by their husbands, in the labour sphere. However, even if the regime accepted this phenomenon as a necessary 'lesser evil' for organising socioeconomic development, the new feminine paradigm represented a threat for many people because of its transgressive nature.

Franco's government tried to control the modernisation process by reminding women that they should not forget their main mission. Feminine broadcasts introduced modern forms of advertising and made small discursive changes that tried to transmit new standards of mass consumption. Nevertheless, there was an ideological continuity with the previous model, a reason why women were urged to maintain their roles of mothers and wives. The radio soap opera is an example that highlights this double role and enjoyed its boom during the pre-developmental period. ${ }^{26}$ Yet, in general terms, the characters in these dramas embodied traditional gender prototypes, which contributed to reinforcing the concept of the hard-working housewife, the devoted mother and the submissive wife. The success of these kinds of broadcasts attracted the first consumer good brands in the country (Cola-Cao, Avecrem, Nestlé) that found a potential site for advertising there. New advertising procedures brought a new form of capitalist consumption to the radio listener. Furthermore, the daily and numerous broadcasts of feminine programmes and the format of a programme divided in episodes produced a new way of listening to the radio. ${ }^{27}$

Kate Lacey poses an engaging argument by envisaging the role of radio in bringing to light the contradictions of modernisation. ${ }^{28}$ She appeals to its innovative sense at the same time that it restored gender relations in a traditional way. The relationship that developed between housewives and the radio in Nazi Germany can be extrapolated to the case of the Spanish dictatorship, 
which outlined women radio listeners as customers and consumers in the same way. Through this series of procedures, the regime transformed the 'modern woman' into an economic and political agent. These changes were transferred to feminine broadcasts, which started to withdraw the concepts of homeland and nation from their vocabulary. The vocabulary became modern simultaneously with the country, and women were individually implored without losing sight of the fact that maternity was the main event to make sense of women's lives. Radio discourse, consequently, focused more on family by illustrating consumption as a new feminine function to take care of the family. Although the changes were obvious, the bond between family and homeland remained in place, and roles within the household did not lose their symbolic and political nature. The difference lay in the fact that Spain did not need to regenerate the 'Hispanic race' at that time; from the Ig6os onward, the establishment of an economic development model and liberalisation were more pressing.

The first week of November 1956 saw the introduction of the programme Vosotras. The importance of this broadcast is based on its long run that stretched from the early years of the dictatorship to its decline. Despite its name change along the way, Vosotras follows the format of the magazine-style programmes from the previous decade like Emisión para la mujer. La moda en España (Broadcast for the Woman. Fashion in Spain) or La hora de la mujer (Women Time). These broadcasts separated their content in several sections divided by subjects, such as beauty, fashion, music, contests, poetry or literature. The first radio speaker of the radio star system, Julita Calleja, managed the feminine broadcast. Luisa Fernanda Martí replaced her in front of the microphone and became the new female star of Radio Madrid. The continuity in

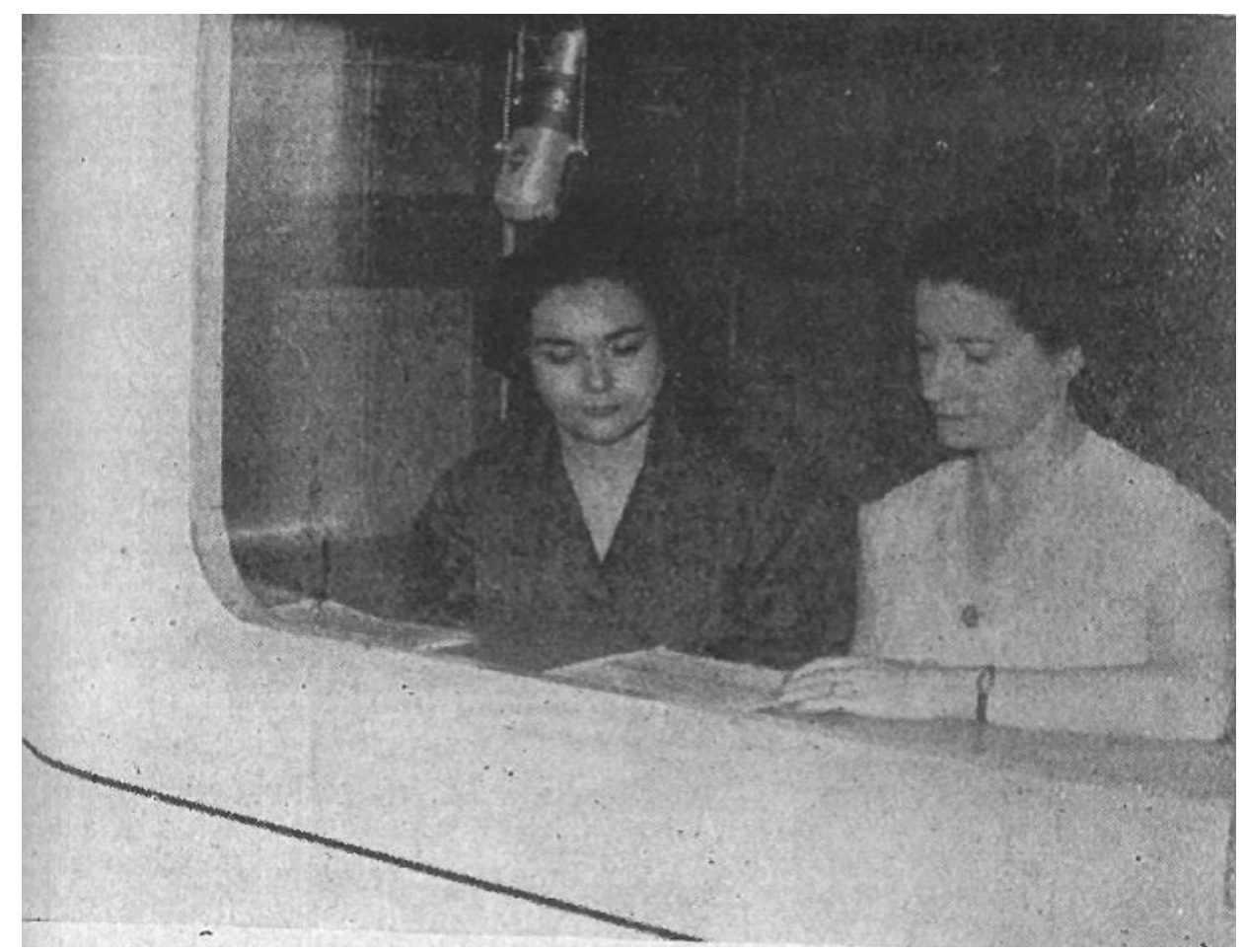

Figure 3. Carmen Brito and Mercedes Laspra during a "Radio Femina" broadcast, Radio Barcelona, Correo de la radio magazine 81 (1959), 91. 
the message of both broadcasts was evident in their common goal to put women back in the domestic sphere. However, due to the changes taking place in the country, there are several aspects that we may examine.

Vosotras emphasised the model of the 'perfect housewife' as the appropriate mode of Spanish women's behaviour:

What should recently married women do in their homes? Well, be on the lookout for all the husband's tastes and have children immediately. Yes, yes, don't panic. The faster you have children, the better. And don't contradict your husband. Let him be comfortable at home when he arrives. Don't badger him with questions (...). Don't laugh, I mean it. The man is good and he has a great innocence. Almost always, woman can do a lot of things. ${ }^{29}$

However, the fact that this message is repetitive of that supported in the previous period did not prevent acceptance of the 'modern woman' model that would gradually be put in place in the Ig6os or the approval of certain feminine patterns that refined the traditional archetype. Maternity and housework continued to be seen as essential feminine experiences. However, the inclusion of single women in the labour market, new ways of consumption and the concept of leisure did lead to the modification of some behaviours and ideologies. Broadcasts tried to deal with any affront to feminine morality through discursive continuity at the same time that they shyly announced some characteristics of the 'modern woman'. The gradual modernisation of bourgeois and well-off middle class homes, the Hollywood aesthetic model, and French fashion were enough of a lure to convince housewives of these social sectors that freedom of consumption represented an important change in their lives. This fact constitutes an obvious rupture with the autarchy years that radio managed to express:

Even if, in reality, today's housewives - I speak in general terms - have a more scientific concept of their mission and they anticipate all the expenses so that the month of January isn't, as in the old times, a tragic course of days, debts, delays and annoyances.... ${ }^{\circ}$

\section{By a way of conclusion}

The cultural mechanisms of the radio to articulate the dictatorial nationalist project based on housewives' tasks were very important. Feminine broadcasts re-educated and indoctrinated women radio listeners by structuring the gender roles that they had to fulfil in order to serve the country. In this way, the political, social and economic changes of the country resonated in the radio sector, which readapted its message to different situations. Over forty years, the radio built and defended the model of the 'perfect housewife', adjusting it in part to the changes that happened in the second Franco era. Therefore, it is not surprising that the famous Consultorio Sentimental Elena Francis (Elena Francis Agony Aunt) still defended in I984 - although in a democratic country - a woman archetype based in the fascist dictatorship. 


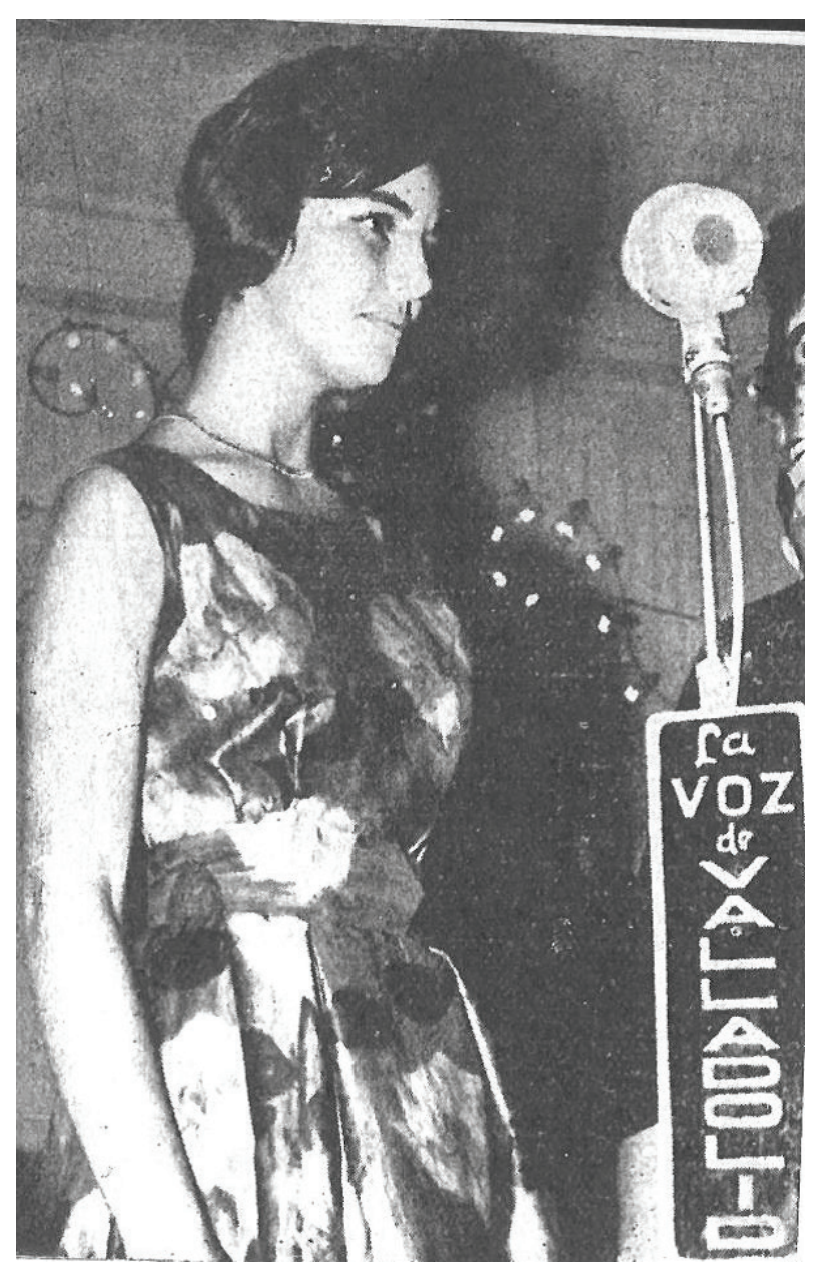

Figure 4. María Teresa Presa, broadcaster for La Voz de Valladolid, Sintonía Magazine 7 (1961), 7.

\section{Notes}

I. Carmelo Garitaonaindia, La radio en España (1923-1939). Del altavoz musical a arma de propaganda [The Radio in Spain (I923-I939). From Musical Loudspeaker to a Propaganda Weapon], (Madrid: Siglo XXI de España Editores, I988), II-84. All the translations of original Spanish citations are by the author.

2. Jordi Gracia and Miguel Ángel Ruiz, La España de Franco (1939-1975). Cultura y vida cotidiana, [The Spain of Franco (I939-I975. Culture and Daily Life] (Madrid: Síntesis, 200I); Mirta Núñez, Los años del terror: la estrategia de dominio y represión del general Franco [The Years of Terror: The Strategy of Control and Repression], (Madrid: La Esfera de los Libros, 2004); Ángeles Egido and Jorge J. Montes, ed., Mujer, franquismo y represión: una deuda histórica [Woman, Francoism and Repression: A Historical Debt], (Madrid: Sanz y Torres, 2018); Encarnación Barranquero, Paloma Navarro and Matilde Eiroa, Mujer, cárcel, franquismo: la prisión provincial de Málaga (1937-1945) [Woman, Prison, Francoism: The Provincial Prison of Málaga], (Málaga: s.n., D.L. I994); Mary Nash, ed., Represión, resistencias, memoria: las mujeres bajo la dictadura franquista [Repression, Resistances, Memory: Women Under Franco's Dictatorship], (Granada: Comares, 2013).

3. The propagandistic sense outlined by the radio is not exclusive to the dictatorial stage, but we can also observe the first signs of this function since its foundation with the speeches of Primo de Rivera or in the Second Republic. This facet was strengthened along the regime and it reached levels unseen before. Garitaonaindia, $\mathrm{La}$ radio en España, 1923-1939.

4. Kate Lacey, Feminine Frequencies. Gender, German Radio, and the Public Sphere 1923-1945 (EE.UU, University of Michigan Press, I996); Caroline Mitchell, ed., Women \& Radio. Radio. Airing Differences, (London and NewYork: Routledge, 2000).

5. Alexander Badenoch, Voices in Ruins. West German Radio Across the 1945 Divide (New York: Palgrave Macmillan, 2008). 
6. Alexander Badenoch analysed radio programmes in post-war Germany as Kreuz und Quer durch Deutschland (All Around Germany) or Echo des Tages (Echo of the Day) to conclude that 'radio stations were possibly more effective than any other institution or effort in occupied Germany at encouraging and enabling democratic participation in formal political processes.' Badenoch, Voices in Ruins, 229. On the other hand, Kristin Skoog points out that radio female BBC programmes served as bridge between housewives and public issues: 'Women could speak politically as housewives. Furthermore, a programme like Woman's Hour clearly had political impact although it was not necessarily a political programme as such. The programme's aim to keep its listeners informed and 'up-to-date' with public matters was also attractive to the political parties.' Kristin Skoog, "«Focus on the Housewife»: the BBC and the Post-war Woman, I945-1955," Networking Knowledge: Journal of the MeCCSA Postgraduate Network 2, no. I (2009), Io, doi: 3II65/nk.2009.2I.35.

7. George Orwell, Looking Back on the Spanish War, (London: New Road, I943). Italics: Orwell.

8. Francisco Reyero, Historia de la radio. Una radografía política, cultural y sentimental del siglo pasado en Andalucía (The History of Radio. A Political, Cultural and Emotional In-Depth Analysis of the Last Century in Andalusia] (Sevilla: Fundación José Manuel Lara, 2006), I24.

9. Lorenzo Díaz, La radio en España (1923-1993) [The Radio in Spain], (Madrid: Alianza Editorial, I993), I47.

Io. Inmaculada Blasco, "Mujeres y nación: ser españolas en el siglo XX" (Women and Nation: Being Spanish Women in the $20^{\text {th }}$ Century], in Ser españoles. Imaginarios nacionalistas en el siglo XX, ed. Javier Moreno and Xosé (Barcelona: RBA, 2013), I92.

II. Teresa María Ortega, “¡Cosa de coser y cantar! La derecha antiliberal y el adoctrinamiento político de la mujer de clase media en la segunda república” [An Easy Peasy Matter! The Anti-Liberal Right and the Political Indoctrination of Middle Class Woman in the Second Republic], in Feminismos y antifeminismos. Culturas politicas e identidades de género en la España del siglo XX, ed. Ana Aguado and María Teresa Ortega (Universitat de València and Universidad de Granada, 20II), I77.

I2. The role assigned to the members of the Sección Femenina is widely discussed. In contrast to the traditional submissive role regarding the male superiority in the Falange, the most recent works have recognized the agencies acquired and, therefore, the heights and relations of power exercised in its space. Inbal Ofer: "A 'New' Woman for a 'Wew' Spain: The Sección Femenina de la Falange and the Image of the National Syndicalist Woman", European History Quarterly 39, no. 4 (2009): 583-605, doi: 10.II77/0265691409342657; Ángela Cenarro, "La Falange es un modo de ser (mujer): discursos e identidades de género en las publicaciones de la Sección Femenina (I938-I945)", [The Falange Is a Way of Being (Woman): Discourses and Gender Identities in Publications of the Sección Femenina (I938-I945)], Historia y Política 37 (20I7): 9I-I20, doi: https://doi. org/IO.I8042/hp.37.04; Susanna Tavera, "Las mujeres de la Sección de Falange: una afirmación entre el activismo político y la sumisión patriarcal, I934-I939" [Women of the Falange’s Section: An Assertion Between Political Activism and Patriarchal Submission, I934-I939], in Feminismos y antifeminismos. Culturas políticas e identidades de género en la España del siglo XX, ed. Ana Aguado and María Teresa Ortega (Universitat de València y Universidad de Granada, 20II), 207-228.

I3. Giuliana di Febo, “'La cuna, la cruz y la bandera”. Primer franquismo y modelos de género" [The Birth, the Cross and the Colors], in Historia de las mujeres en España y América Latina IV. Del siglo XX a los umbrales del siglo XXI, ed. Isabel Morant (Madrid: Cátedra, 2006), 221.

I4. Pilar Primo de Rivera, Discurso, circulares, escritos [Speeches, Memos, Documents] (Madrid: Sección Femenina de las FET y de las JONS, n.d.), 36.

I5. Four months before, in March I94I, this programme first appeared under the name of Charla médica (Medical Talk), but it would take its final name shortly after. The programme was extended until the first half of I945 and it reappeared again in I950 but this time under the name of El mundo de los niños (The Children's World).

I6. In I945 some reorganization of programming took place and the programme was broadcast at I9.45 or at 20.30 with intermittent changes during the first half of the year. In I950, it was broadcast twice a week.

I7. Archivo General de la Administración (AGA, General Archives of the Administration), Radio Madrid, “Cuadernillo de programación de Radio Madrid” (Radio Madrid's Programming Booklet), (3), 49.0I, Box 2I/23.

I8. Irene Palacio, Mujeres ignorantes: madres culpables. Adoctrinamiento y divulgación materno-infantil en la primera mitad del siglo XX (Ignorant Women: Guilty Mothers. Indoctrination and Maternal-Infant Dissemination During the First Half of the $20^{\text {st }}$ Century], (Universitat de Valéncia, 2003), 3I-37.

I9. AGA, Radio Madrid, "Cuadernillo de programación de Radio Madrid”, (3), 49.0I, Box 2I/32.

20. 'El Caudillo' (which means 'the leader') was the title used to refer to Francisco Franco.

2I. AGA, Radio Madrid, “Cuadernillo de programación de Radio Madrid," (3), 49.0I, Box 2I/27. 
22. Badenoch, Voices in Ruins, 8.

23. Blasco, “Mujeres y nación," I96.

24. Carmen Romo, El extraño viaje del progreso. Discursos sobre la cotidianidad e identidades femeninas durante el desarrollismo franquista (The Strange Development Trip. Discourses About Everyday Life and Feminine Identities During the Francoist Developmentalism) (Sevilla: Athenaica, 20I7). In France the role of the woman as consumer was already noticeable ten years earlier; see for example Rebecca Pulju, "Consumers for the Nation. Women, Politics and Consumer Organization in France, I944-I965," Journal of Women's History I8, no. 3 (2006): 68-90 and Anya Luscombe, "Eleanor Roosevelt and Radio in Early Cold War France," Women's History Review (2019), doi: 10.1080/09612025.2019.1600646.

25. Armand Balsebre, Historia de la radio en España (1939-1985) Vol. II (History of the Radio in Spain) (Madrid: Cátedra, 2002), 2II.

26. Elena Ayuso "La recepción de la radio dramática en España (desde la posguerra a I97I)" (The Reception of the Radio Drama in Spain (From the Post War Era to I97I)), Index. Comunicación 3 (2013): I65-I85, http://journals. sfu.ca/indexcomunicacion/index.php/indexcomunicacion/article/view/65/69, latest visit 4 January, 2019.

27. Armand Balsebre affirms that feminine broadcasting in the I940s served as a test of the advertising sponsorship's commercial system and at the same time generated the consumption patterns of house products. In this sense, we can argue that the radio strengthened an autarchy model in presenting its austerity in advertising models and the discourse of its programmes. At the same time, it behaved in the same way when presenting new capitalist mechanisms to housewives. Balsebre, Historia de la radio, 156.

28. Lacey, Feminine Frequencies, I73.

29. AGA, Radio Madrid, "Cuadernillo de programación de Radio Madrid”, (3), 49.03, Box I7.555.

30. AGA, Radio Madrid, "Cuadernillo de programación de Radio Madrid”, (3), 49.03, Box I7.562.

\section{Biography}

Sergio Blanco Fajardo is a PhD candidate at Malaga University working on a doctoral thesis that examines female radio broadcasts during the first Franco regime (I939-I959). He obtained a BA in History and an MA in Gender and Equality from Malaga University He has participated in the research project 'The Voice of Women in Public Space: XVIII-XX Centuries,' HAR20I4-53699-R. He published on Latin American women and human rights, in Arena. Revista de historia de las mujeres (2016) and Alcores: revista de historia contemporánea (2018). 